\title{
Designing low carbon buildings: A framework to reduce energy consumption and embed the use of renewables
}

\author{
Saad Dawood ${ }^{\mathrm{a}, *}$, Tracey Crosbie ${ }^{\mathrm{a}}$, Nashwan Dawood ${ }^{\mathrm{a}}$, Richard Lord ${ }^{\mathrm{b}}$ \\ a Centre for Construction Innovation and Research, Teesside University, Middlesbrough, TS1 3BA, UK \\ ${ }^{\mathrm{b}}$ Centre Technology Futures Institute School of Science E' Engineering, Teesside University, Middlesbrough, TS1 3BA, UK
}

\section{A R T I C L E I N F O}

Keywords:

Low carbon building design

Renewable energy technology and energy analysis

\begin{abstract}
A B S T R A C T
EU policies to mitigate climate change set ambitious goals for energy and carbon reduction for the built environment. In order meet and even exceed the EU targets the UK Government's Climate Change Act 2008 sets a target to reduce greenhouse gas emissions in the UK by at least $80 \%$ from 1990 levels by 2050 . To support these targets the UK government also aims to ensure that $20 \%$ of the UK's electricity is supplied from renewable sources by 2020 . This article presents a design framework and a set of integrated IT tools to enable an analysis of the energy performance of building designs, including consideration of active and passive renewable energy technologies, when the opportunity to substantially improve the whole lifecycle energy performance of those designs is still open. To ensure a good fit with current architectural practices the design framework is integrated with the Royal Institute of British Architects (RIBA) key stages, which is the most widely used framework for the delivery of construction projects. The main aims of this article are to illustrate the need for new approaches to support low carbon building design that can be integrated into current architectural practice, to present the design framework developed in this research and illustrate its application in a case study.
\end{abstract}

(c) 2013 Elsevier B.V. All rights reserved.

\section{Introduction}

European policies to mitigate climate change set ambitious goals for energy and carbon reduction from the built environment (European Commission, 2008). In order meet and even exceed the EU targets UK Government's Climate Change Act 2008 sets a target to reduce greenhouse gas emissions in the UK by at least $80 \%$ from 1990 levels by 2050 (Department of Energy, 2011). To support these targets the UK Government also aims to ensure that 20\% of the UK's electricity supply is from renewable sources by 2020 (Department of Energy, 2011). Unsurprisingly given the ambitious goals for both carbon reduction and renewable energy generation the Government has introduced many different policies to support both an improvement in the quality of the UKs' building stock and the use of renewable energy technologies. For example, part L of the Building Regulations, introduced in 2006, imposes new requirements aimed at improving the energy efficiency of the domestic and non domestic building stock. A renewable energy scheme to encourage homeowners to use active renewable energy technologies, such as solar panels, has also been established (Department of Trade \& Industry, 2007). In addition a number of measures to encourage the use of renewable energy in the commercial sector, some punitive

\footnotetext{
* Corresponding author. Tel.: +44 7704334375.

E-mail address: saad.dawood@btinternet.com (S. Dawood).
}

and some encouraging, have been initiated. For example, Enhanced Capital Allowances (ECAs) enable a business to claim $100 \%$ of firstyear capital allowances on their spending on qualifying plant and machinery (Energy Capital Allowance, 2010). The recognition of the need for carbon reduction from the built environment, along with new EU directives, more stringent building regulations and general environmental concerns, is also encouraging the development and application of sustainable building codes. In the UK these include the Standard Assessment Procedure (SAP) and the Simplified Building Energy Model (SBEM), the Code for Sustainable Homes (CSH) and the Building Research Establishment Environmental Assessment Model (BREEAM).

Against this backdrop of European and UK carbon reduction targets, policies, regulations and codes to support, renewable energy generation and carbon reduction, this article presents a framework and a set of integrated IT tools to enable an analysis of the energy performance of building designs. These tools and methods have been developed to support low carbon building designs which reduce energy consumption and increase the use of renewable energy technologies. It is essential that the framework supports design decisions made early in the design process before investment decisions are finalised and applications for planning permission are made. This is because many of these decisions, such as, building orientation, building shape, use of renewable resources and glazing ratios etc., have a huge impact on the energy performance of a building and are usually impossible to change during 
the later stages of the design process (Loh, Crosbie, Dawood, \& Dean, 2010; Olofsson et al., 2011; Schlueter \& Thesseling, 2009). In particular the use of both passive and active renewable energy technologies have a significant impact on a buildings energy performance, as well as impacting on building emissions rates, build cost and the application of regulatory frameworks (National Institute of Building Sciences, 2010). Given the importance of the decisions made during the early stages of building design it is surprising that energy assessments are not usually conducted until the later stages of building design. Currently these are predominantly limited to sizing HVAC systems and ensuring compliance with building regulations once planning permission has been granted (Crosbie, Dawood, \& Dean, 2010; European Commission, 2008).

One of the main goals of the research presented in this article is to move consideration of the issues related to energy performance and sustainability to the earlier stages of building design process when the opportunity to significantly improve the energy performance of a building design is still open. To achieve this it is essential that new approaches to support sustainable design are integrated with current architectural business practice. To ensure a good fit with current business practices the framework presented is informed by interviews with professionals working for architectural companies. This approached lead to the integration of the framework with the Royal Institute of British Architects (RIBA) key stages, which is the most widely used framework for the delivery of construction projects within the UK and elsewhere (McElroy, 2009).

In essence the framework presented aims to integrate existing technologies and sustainable building codes to bridge the gaps in current approaches to low carbon design. This includes the integration of;

- Energy simulation tools and approaches for the analysis of building energy performance including estimations of the potential of active renewable energy technologies,

- National Calculation Methods (NCM) and codes to support energy efficient and sustainable buildings,

- Multi-Criteria Decision-Making (MCDM) approaches and tools designed to support stakeholder decision making in the building design process.

The framework is developed so that an architect can iteratively re-design a building and immediately see if the air pollutant emissions, energy consumption, or operating costs, have been reduced or increased by different design options. This ensures that designers, clients and stakeholders have the relevant information required for an assessment of cost versus environmental impact with regard to different aspects of a building's design. In this way building owners and users will have the opportunity to minimise operating costs and optimise performance over the building's lifetime.

The remainder of this article is divided into three sections. The first, illustrates the need for new methodologies and integrated tools to support sustainable design by presenting a review of building energy simulation tools, sustainable building codes and their application in current design practice. The next section then goes on to outline the design framework developed in this research to support the integration of the design methods and tools required for sustainable design practice into current architectural business practices. The third section presents a case study to illustrate how the framework can be used in a low carbon design process. The fourth and final section discusses the research findings, draws some conclusions and presents the future research avenues these conclusions suggest.

\section{Gaps in current approaches to building design}

\subsection{Building energy simulation tools and their application}

Building energy simulations are conducted by design professionals (architects, engineers and energy consultants etc.) using building design and energy analysis software tools to analyse the energy performance of their designs. For example, the energy performance feedback provided by whole building energy analysis tools allows designers to assure equipment is properly sized for the design conditions of a given building and that the part-load performance of buildings' subsystems provide a comfortable environment (Jacobs \& Henderson, 2002). A database developed by the U.S. Department of Energy (DoE) currently lists almost four hundred energy tools designed to simulate the energy performance of buildings and/or their components (US Department of Energy, 2011). Many of these building simulation tools are designed to be used during different phases of the building design lifecycle and have different functionalities. For example, some whole-building simulation tools are capable of simulating the use of the most common active renewable energy technologies, such as, wind turbines and photo voltaic (PV) panels and some support selected National Calculation Methods (NCM) and codes for sustainable buildings. See Table 1 , which presents a selection of widely used whole building simulation software highlighting the differences in their functionalities. There are also some stand alone tools to assess the effectiveness of the most common active renewable energy technologies at the building level, see Table 2 , which presents a selection of the tools available and details their geographic applicability and output.

Table 1

Comparison of the functionality of whole building energy simulation tools.

\begin{tabular}{|c|c|c|c|c|}
\hline Tool attributes & SBEM $^{\mathrm{a}}$ & IES-VE v6. $1^{\mathrm{b}}$ & TAS $^{\mathrm{c}}$ & Design builder $^{\mathrm{d}}$ \\
\hline Integrated with BIM & $\mathrm{N}$ & $\mathrm{Y}$ & $\mathrm{N}$ & $\mathrm{Y}$ \\
\hline Dynamic simulations & $\mathrm{N}$ & $\mathrm{Y}$ & Y & Y \\
\hline Consideration of internal shading & $\mathrm{Y}$ & $\mathrm{Y}$ & $\mathrm{Y}$ & $\mathrm{Y}$ \\
\hline Consideration of external shading & $\mathrm{N}$ & $\mathrm{Y}$ & Y & Y \\
\hline Geometry/graphic approach & $\mathrm{N}$ & $\mathrm{Y}$ & $\mathrm{Y}$ & $\mathrm{Y}$ \\
\hline Unlimited orientations & $\mathrm{N}$ & $\mathrm{Y}$ & $\mathrm{Y}$ & $\mathrm{Y}$ \\
\hline Renewable technologies & $\mathrm{N}$ & $\mathrm{Y}$ & $\mathrm{Y}$ & $\mathrm{N}$ \\
\hline Global climate data & $\mathrm{N}$ & $\mathrm{Y}$ & $\mathrm{Y}$ & $\mathrm{Y}$ \\
\hline Calculation of natural ventilation & $\mathrm{N}$ & $\mathrm{Y}$ & $\mathrm{Y}$ & $\mathrm{N}$ \\
\hline Building regulation Part L & Y & $\mathrm{Y}$ & $\mathrm{Y}$ & $\mathrm{Y}$ \\
\hline Easy to use & $\mathrm{N}$ & $\mathrm{Y}$ & $\mathrm{N}$ & $\mathrm{Y}$ \\
\hline Construction cost & $\mathrm{N}$ & $\mathrm{Y}$ & $\mathrm{N}$ & $\mathrm{N}$ \\
\hline
\end{tabular}

a SBEM, Simplified Building Energy Model, v3.5.b, 2011, http://www.ncm.bre.co.uk/.

b IES-VE, Integrated Environmental Solutions, v6.1, 2011, http://www.iesve.com.

c TAS Software, Environmental Design Solutions Limited (EDSL), v9.1.4.1, 2010, http://www.edsl.net/main/Software.aspx.

d Designbuilder software, v2.4, 2010, http://www.designbuilder.co.uk. 
Table 2

Geographic applicability and output of standalone tools to assess micro renewable energy technologies.

\begin{tabular}{|c|c|c|c|}
\hline Tools & Type & Location & Output \\
\hline SWERA - Renewable energy Resource EXplorer (RREX)a & Solar wind & Global & Wind speed, solar irradiance, temp \\
\hline Carbon Trust ${ }^{\mathrm{b}}$ & Wind & UK & $\mathrm{CO}_{2}$ saving, energy generation, wind speed \\
\hline PV potential estimation utility ${ }^{c}$ & Solar & EU Africa & Solar resources, photovoltaic potential \\
\hline European Wind Atlas ${ }^{\mathrm{d}}$ & Wind & EU & Wind speeds, cost, types of wind turbine \\
\hline Biomass Environment Assessment Tool (BEAT)e & Biomass & Global & $\mathrm{CO}_{2}$ emission, environmental impact, cost \\
\hline Solar PV Feed in Tariff Calculator (SPVFTC) ${ }^{\mathrm{f}}$ & PV & UK & Energy generation, life time saving, payback period \\
\hline
\end{tabular}

a SWERA, Renewable energy Resource Explorer, 2011, http://na.unep.net/swera_ims/map2.

b Carbontrust, Wind Yield Estimation Tool, 2010, http://www.carbontrust.co.uk/publicsites/WPEstimator/Default.aspx.

c PV, potential estimation utility, 2010, http://re.jrc.ec.europa.eu/pvgis/.

d European Wind Atlas, 2011, http://www.wind-energy-the-facts.org/en/part-i-technology/chapter-2-wind-resourceestimation/wind-atlases.html\#table2.1.

e BEAT2, Biomass Environment Assessment Tool, 2011, http://www.biomassenergycentre.org.uk/portal/page?_pageid=74,153193\&_dad=portal\&_schema=PORTAL.

f SPVFTC, Solar PV Feed in Tariff Calculator, 2011, http://www.energygrants.co.uk/solar_power/solar-pv-feed-in-tariffcalculator.html\#anchor.

While there are gaps in the functionality of building simulation tools in terms of their ability to simulate unusual building designs and some renewable energy technologies this is not the major problem. The main issue is that building energy simulation tools are currently used after many of the decisions which affect the energy performance of buildings, such as, building orientation, building shape, use of renewable resources and glazing ratios, have been finalised (Crosbie et al., 2010). The use of tools to estimate the value of active renewable energy technologies is also limited during the early phases of building design (Crosbie et al., 2010).

Many general lifecycle design frameworks to support energy efficient buildings have also been developed (Olofsson et al., 2011). However the approach adopted often demands that architects and building contractors completely transform current building design practice, which may be desirable but is not feasible (Loh et al., 2010). This problem is exacerbated by the many other barriers to the adoption of building energy simulation tools by architects and building design consultants (Crosbie et al., 2010). These include the steep learning curve required to enable the use of energy simulation tools and the extensive data input required. The amount of time that it is necessary to dedicate to enter data in the energy analysis programs is repeatedly mentioned by researchers as one of the main obstacles to be overcome (Bazjanac, 2003; Hand, Crawley, Don, \& Lawrie, 2008; Klein, Versele, \& Breesch, 2008; Neuberg, Rank, Ekkerlein, \& Faulstich, 2003). The time dedicated to process and re-create the geometry generated with a BIM authoring tool to conform with the format required by an energy analysis software amounts to up to $50 \%$ of the time a project team dedicates to performing an energy simulation (Krygiel, Nies, \& Green, 2008). The level of expertise necessary to interpret the results of energy simulations is a further barrier to the use of energy profiling in the design of buildings (Schlueter \& Thesseling, 2008).

Attempts are being made to overcome the barriers to the use of tools to simulate the energy performance of buildings during their design. For example, whole building simulation tools are integrated with BIM software to reduce data entry requirements (see Table 1). However, it must be noted that none are fully integrated and some level of work is required to 'fix' the models imported into whole building energy simulation tools from BIM tools before it is possible to run simulations (Karola et al., 2002). It must also be noted that of the many energy simulation tools currently available very few provide a holistic and integrated approach to sustainability analysis (Crosbie et al., 2008). This is partly because these are mostly modular software designed to simulate different aspects of a building design individually rather than supporting an integrated analysis of the energy performance of a whole building (Armines, Circe, Kth, et al., 2010). This is related to current building design practice which, as discussed earlier, tends to neglect issues of sustainability and the requirements for energy assessment until the later stages of the building design process. This approach is encouraged by the current application of building regulations and codes for sustainable design as discussed in the following section.

\subsection{The application of building regulations and codes for sustainable design}

The Energy Performance of Buildings Directive (EPBD) 2002/91/EC of the European Parliament and Council requires that the energy performance of new buildings are evaluated using a calculation methodology which complies with the Directive. In response the UK Department for Communities and Local Government (DCLG) commissioned the National Calculation Methodology (NCM) for energy performance in buildings (Communities and Local Government, 2008). The results of this process are SAP for measuring the energy rating of dwellings and SBEM for measuring the energy rating of non-domestic dwellings. These two methodologies are used to assess compliance with the 2006 amendments to Part L of the UK Building Regulations which aim to improve the energy performance of the UK building stock by introducing new energy efficiency requirements for all new buildings.

SAP and SBEM are also used to check compliance with sustainable building codes. These include the CSH and BREEAM. The CSH was introduced in 2007 as a tool to achieve the 'step-change' required to improve the overall environmental performance of new housing (McManus, Gaterell, \& Coates, 2010). The code measures the sustainability of a new home against nine categories of sustainable design, rating the 'whole home' as a complete package, including: energy $/ \mathrm{CO}_{2}$, water, materials, surface water run-off, waste, pollution, health and well-being and ecology. It uses a 1 to 6 star rating system to communicate the overall sustainability performance of a new home (Communities \& Local Government, 2006). The BREEAM (Building Research Establishment, 2011) code is used for non-domestic buildings; it sets the standard for best practice in sustainable design and has become the de facto measure used to describe a building's environmental performance of non-domestic buildings. It can be tailored for assessing an individual project (bespoke) or various generic building types, such as an office, healthcare buildings, prisons and courts. It includes a section on energy efficiency and $\mathrm{CO}_{2}$ emissions amongst other environmental considerations. Credits are awarded in ten categories according to performance. These credits are then added together to produce a single overall score, which is compared to a scale for Pass, Good, Very Good, Excellent and Outstanding buildings.

However, building regulations and sustainable building codes standards do not require dynamic simulation of the performance of building designs. Therefore, at the design stage, the modelling of performance is often restricted to checking that a building design will meet the minimum criteria (i.e. building regulations). In the case of BREEAM and the CSH assessments are conducted once a building is completed, rather than during the design development and contractors only allocate time at the end of the construction 
phase of buildings to obtain BREEAM credits or compliance with CSH (McElroy, 2009). As will be detailed in section 3 the framework developed in this research seeks to obtain maximum CSH/BREEAM points during the design of a building in order to maximise a build's sustainable potential.

\subsection{Current architectural practice and low carbon design}

Howarth and Hadfield noted that "The issues of sustainability are often neglected in design or expected to be someone else's responsibility" (Howarth \& Hadfield, 2006), Nielsen added "The energy performance aspects are often not assessed before the detailed building design has been decided. At this stage of the design process only small changes to the building design is possible and the changes often result in high extra expenses."(Nielsen, 2002) Accordingly "Decisions made during early stages of a building design process would have substantial impact on the performance of the resulting building." (Pollock, Roderick, McEwan, \& Wheatly, 2009). The neglect of sustainability issues during the early building design process is not only embedded within the application of building regulations and sustainable building codes and pervious work, it is also reflected in the 'RIBA Plan of Work Stages.' This is important as the 'RIBA Plan of Work Stages' is the most widely used framework for the delivery of construction projects in the UK and elsewhere (RIBA, 2008). It describes activities involved in the design and construction process, from appraising the client's requirements through to post construction (RIBA, 2008). It divides the design and construction process into eight stages from A to M (RIBA, 2008). In general, stages $A$ and $B$ focus on project feasibility, stages $C$ to $\mathrm{H}$ are mainly concerned with the pre-construction process whilst stages $\mathrm{J}$ to $\mathrm{M}$ are concerned with the site construction process. However it is widely argued that the 'RIBA Plan of work stages' overlooks the environmental responsibility of Architecture, Engineering and Construction professionals because it does not support the inclusion of environmentally sound design decisions in the early phases of building design (Loh et al., 2010). The design framework presented in the following section seeks to remedy this problem by ensuring that codes for low carbon design and dynamic simulations of the energy performance of building designs are integral to the early design process.

The approach adopted is informed by interviews with five senior staff working in large architectural practices in the UK, which were used to inform and validate the development of the framework. Interviewees were given a short presentation outlining the proposed framework. The subsequent questions focused on identifying the key criteria related to energy performance that interviewees think it is advantageous to address within the design process and how consideration of these issues can be further integrated into current working practices. The interviews highlighted the following issues:

- Any process adopted must be compatible with the RIBA work stages;

- The assessments of BREEAM/CSH credits as early as possible in the deign process is advantageous;

- Building orientation, shape and wall-window ratio have the most significant impact on energy performance;

- Consideration of both passive and active renewable energy technologies is essential;

- Occupant comfort must be included in any energy optimisation process of building designs;

- Integration of energy simulation tools with BIM tools is necessary to reduce the time required to run energy simulations;

- Any process adopted must have the flexibility to ensure that client requirements can be prioritised.
The approach developed in the framework described in the following section is based on the findings from the interviews. It is similar to that which the interviewees said they would like to adopt but felt that a lack of knowledge about the most appropriate assessment tools prevented them from doing so. However interviewees felt that the process could be used to underpin an approach that an architectural practice may be inspired to follow if the assessment tools became available. This prompted the development of a Sustainable Design Optimisation Tool (SDOT) to simplify the process of checking multiple design options for design compliance with sustainable building codes and to support design optimisation. This tool and its functionalities are further discussed in the following section and its application is demonstrated in the case study in section four.

\section{A framework for integrating low carbon design into architectural practice}

\subsection{Incorporating sustainability assessments into RIBA work stages}

At the outset of a project, during stages A to B of the 'RIBA Work Stages', an initial appraisal is carried out to identify project constraints, procurement route, stakeholders and to develop an outline of the building design. During this process all relevant regulations and legislation are referenced to ensure the project meets legal requirements, and the strategic brief prepared by the client containing their initial requirements is sent to the architect. In stage $C$ of the 'RIBA Work Stages' the outline designs of a building, developed in stages $A$ and $B$, are detailed to the extent that an approximation of construction costs and information for cost planning can be provided. This enables client approval to be sought for a building design and its associated costs and also provides the information for planning applications' ${ }^{1}$. Thus stage $C$ of the 'RIBA Work Stages' provides an ideal opportunity to demonstrate different design options with regard to energy performance, financial costs and sustainability rating (Loh et al., 2010). The framework presented seeks to incorporate assessments of the various codes for low carbon design and dynamic simulations of the energy performance of building designs into stage $\mathrm{C}$ of the design process (see Fig. 1).

The initial input into stage $\mathrm{C}$ is the outline design proposal developed in stages A and B. It is suggested here that different design alternatives are developed which meet the clients brief based on the outline designs in what we have called stage $\mathrm{C} 1.1$. These alternative designs, where possible should include different options for building orientation, shape, wall-window ratio and passive renewable energy technologies (such as buffer zone, solar walls, etc.). Following this, in what we have called stage $\mathrm{C} 1.2$, the possible $\mathrm{CO}_{2}$ saving, energy generation value, implementation and lifecycle costs for a selection of active renewable energy technologies are calculated. This is necessary to enable the design team and clients to make an informed decision concerning the inclusion of micro generation renewable energy technologies. However, there are some gaps in relation to the availability of tools to make the required assessments, which are highlighted by the case study in the following section.

Once the decision about renewable energy technologies is made, an energy simulation tool is used to assess the energy costs, heat

\footnotetext{
${ }^{1}$ During stage $\mathrm{C}$ of the 'RIBA Work Stages' a full set of tendering documentation including design brief, site data, project schedule, project budget and client requirements are prepared and given to tendering contractors/architects to prepare the full design proposal. Following stage C in stage D of the 'RIBA Work Stages', investment decisions are finalised and applications for planning permission are made.
} 


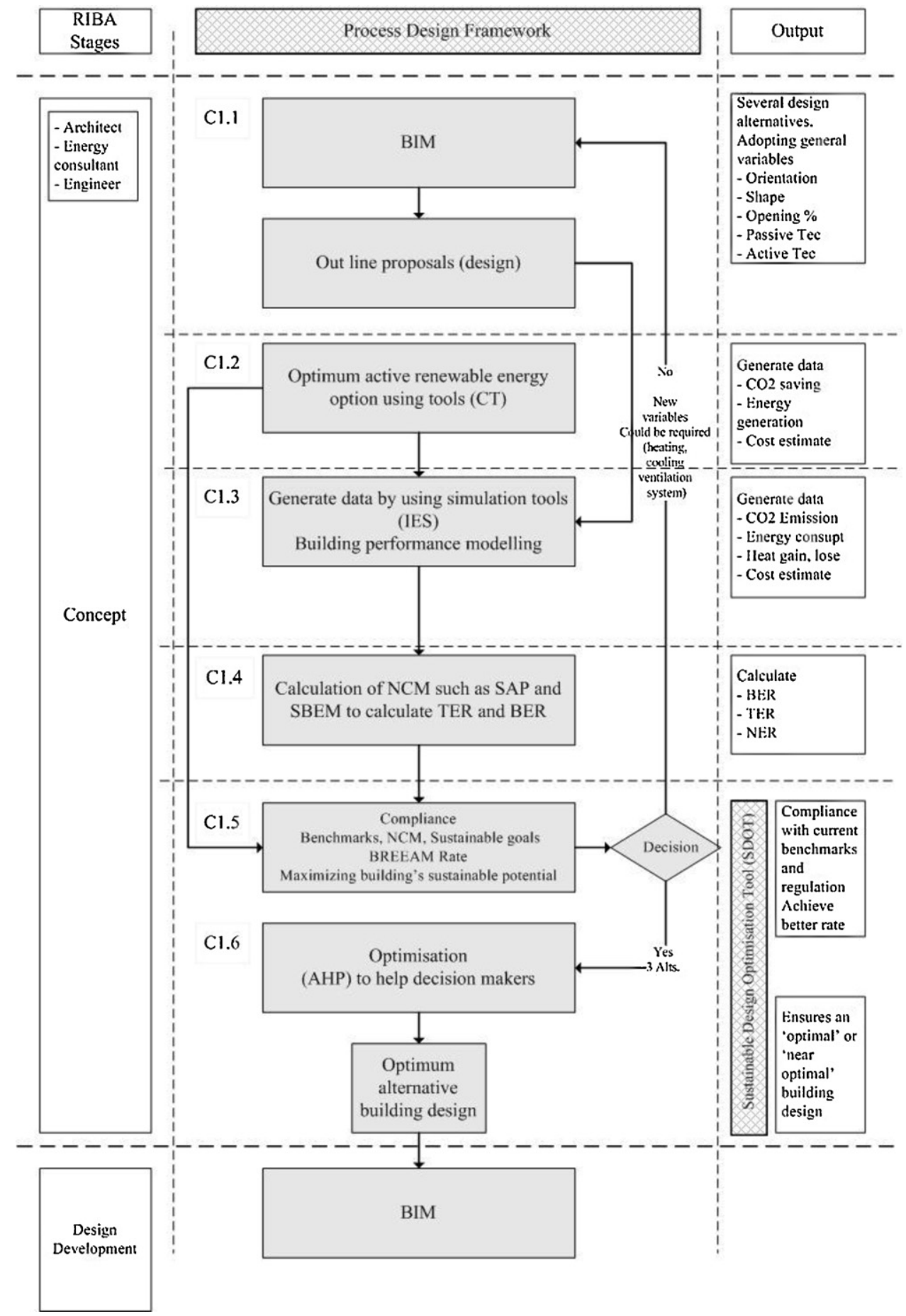

Fig. 1. Detailed design process framework for RIBA stage C.

gain/loss, and $\mathrm{CO}_{2}$ emissions of each of the design options in stage C1.3. Also as part of $\mathrm{C} 1.3$ capital cost is calculated using cost tools and estimating software. The cost data can be obtained from price books however, some whole building simulation tools such as IES include modules capable of estimating construction cost. In stage C1.4 the relevant national calculation methods are used to assess the building designs. In the UK this is SAP for domestic buildings and SBEM for non-domestic buildings. These are used to calculate Target Emission Rate (TER) and Building emission Rate (BER) to check compliance with the building regulations.

As detailed in Table 1, there are numerous whole building simulation tools capable of conducting these calculations. However, it was necessary to develop a Sustainable Design Optimisation tool to simplify the processes conducted in stage C1.5 (design compliance) and stage C1.6 (design optimisation), as the interviews indicated that if these process are too onerous and time consuming they will be rejected by architectural professionals.

The Sustainable Design Optimisation tool incorporates a database, used in stage C1.5, to check the outputs of the national calculation methods applied in stage C1.4 and the outputs of the simulations from stage C1.3 against benchmarks and building regulations. Checking the outputs of the national calculation methods at this stage of the design process enables the design team to assess the BREEAM or CSH credits available from each design option. The 


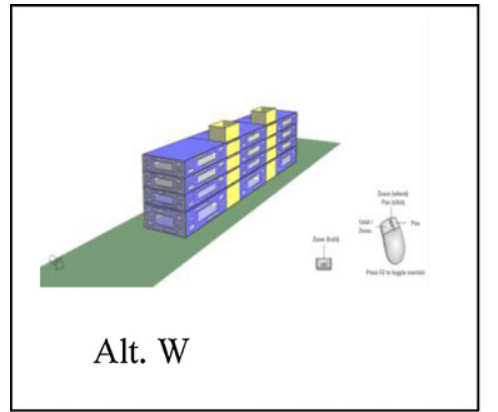

Alt. W
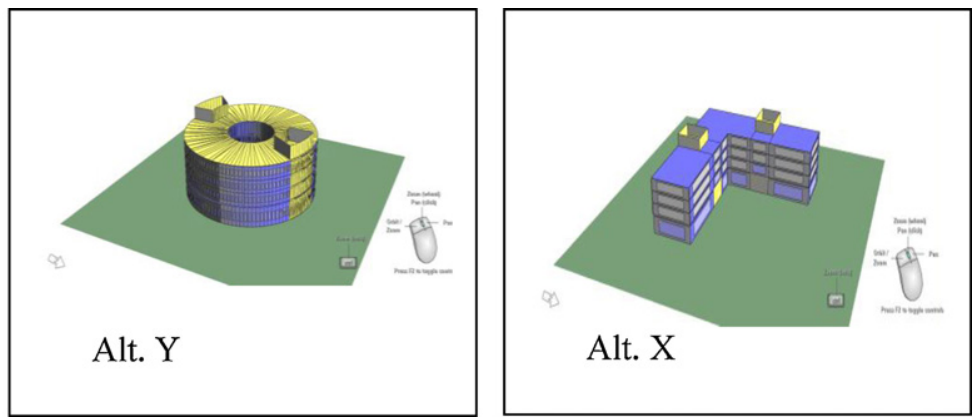

Fig. 2. Design alternatives.

output of stage $\mathrm{C} 1.5$ is at least three building designs that pass the relevant benchmarks and building regulations, while meeting the client's requirements. If this is not the case, the whole process is conduced again. At this stage it is possible to use the findings of the energy simulations of the current designs to produce a hybrid design by merging the best design options from each. However if a hybrid design is developed it must be checked against the relevant sustainability standards, regulations and benchmarks and the client's requirements.

In stage $\mathrm{C} 1.6$ clients and/or other stakeholders select the design which most closely fits their requirements. To support their decision making the Sustainable Design Optimisation tool incorporates a decision support module. This module uses a Multi-Criteria Decision-Making (MCDM) approach called Analytic Hierarchy Process (AHP) (Saaty, 1990). The AHP is used because it supports trade-offs with and without tangible values. Or in other words, this approach enables the subjective opinions of the design team to be taken into account. In this way AHP acknowledges that decision making engages with solid, verbal and subjective elements (Saaty, 1994), while enabling tangible values to be used for compliance with building regulations and sustainability codes. It allows stakeholders to evaluate and choose amongst alternatives based on multiple criteria using a systematic analysis that overcomes the limitation of unstructured individual or group decision-making (Keller \& Kirkwood, 1999). The output of stage C1.6 is a single "optimal" or "near optimal" building design, in that it is the most energy efficient outline design possible that meets both the relevant planning regulations and the client's requirements.

\section{Case study}

To check the viability of both the framework presented in the previous section and the tools available to conduct the necessary assessments, a case study was conducted using a possible design process for a multi story social housing apartment building to be situated in Manchester. It is hypothesised that the social housing provider requires 24 flats within a single building with a total floor area of not more than $2460 \mathrm{~m}^{2}$. It is assumed that the client brief contains an aspiration that the building will employ passive renewable energy technologies and comply with the CSH regarding the use of renewable energy sources. It is also assumed that the social housing provider is concerned about the cost of renewable energy technologies and therefore wants to meet the minimum regulatory requirement by ensuring that $10 \%$ of the buildings energy needs are met by renewables, but does not want to invest further in active renewable energy technologies.

The first step involved developing three design alternatives for the apartment building that meet the hypothesised client brief (see Fig. 2). Each of the alternatives includes different options for the shape and orientation of the building, the type, area and orientation of windows and levels of solar mass in the walls and roofing.
The next phase involved the assessments of $\mathrm{CO}_{2}$ savings and energy generation values of different active renewable energy technologies (see stage C1.2 in Fig. 1). There are a wide range of renewable energy sources/technologies, varying in technical and commercial viability (CIBSE Guide, 2004). In this case study the active renewable energy technologies assessed are PV panels, wind turbine, Biomass boiler and Ground source heat pumps (GSHP). These were selected because they are argued to be the most cost-effective options (Bevan, Cavanagh, \& Broks, 1994; Donnellan, 2008; Omer, 2008).

IES was used to make the assessment of PV, the Technology of Renewable Energy Company's [TRECO] tool was used in the case of biomass and Carbon Trusts wind estimation tool was used to assess the viability of wind turbines. However, no tool is currently available to assess GSHP and it was necessary to use manual calculations. The capital costs used in the assessments are based on those given by the suppliers of renewable technology (Segen Developer, 2011). The outputs of these assessments are shown in Table 3. The payback period for a wind turbine is 27 years, leaving only 3 years within the lifespan of the technology for the client to make savings on energy costs. For PV the payback period, at 23 years, is not much better than in the case of wind. In the case of GSHP the payback period is 13 years, leaving 17 years within the lifespan of the product for the client to make savings. In the case of GSHP the saving will be $£ 3400$ each year giving a total saving of $£ 57,800$. For biomass the payback period is 6 years, the saving will be $£ 3440$ each year giving a total $£ 82,560$ saving over the life span of the product. Therefore it would seem that biomass is the best option financially. However biomass boilers require a storage area and a regular supply of bio fuel. There are currently concerns over the wider sustainability of biomass and a government review of this aspect is in preparation (Committee on Climate Change report, 2010). In an urban setting the particulate emissions from such a system might also be of concern to regulators. We have assumed that these limitations might lead the social housing provider to also the next most financially viable options, such as GSHP.

In the next stage (see Fig. $1 \mathrm{C} 1.3$ ) an energy simulation tool (in this case IES) is used to assess the energy consumption, $\mathrm{CO}_{2}$ emissions, capital costs and comfort-occupied ${ }^{2}$ for each of the design options (see Table 4) and the relevant national calculation methods are used to assess the building designs (see Fig. 1 stage C1.4). In the case of social housing this is SAP for domestic buildings (The Government's Standard Assessment Procedure for Energy Rating of Dwellings, 2005). In this case study these calculations were con-

\footnotetext{
2 This is a measure used to assess the ability of a passive system to maintain comfort (minimise temperature fluctuations) which is controlled by the size, placement and properties of the thermal mass in the system (Davis and Schubert, 1981). The percentage of people that will find the room thermally uncomfortable (PPD) is a measurement of this criteria, in the UK guidelines state that comfort lies between 5 and 20\% PPD (CIBSE, 2006).
} 
Table 3

Comparison between wind turbine, GSHPs, Biomass boiler and PV.

\begin{tabular}{|c|c|c|c|c|c|c|c|c|}
\hline Renewable option & Capital cost $£$ & Period of 30 years & Profit a year $£$ & Assessment tools & $\mathrm{kW}$ & Height\& area & kWh/year & $\begin{array}{l}\mathrm{CO}_{2} \text { saving } \\
\mathrm{kgCO}_{2} / \text { year }\end{array}$ \\
\hline Wind turbine & 95,950 & 104,100 & $3470 \times 3$ year & Carbon Trust & 30 & 25 & 20,429 & 10,970 \\
\hline $\mathrm{PV} 40^{\circ} / 0^{\circ}$ & 81,650 & $106,05017 \mathrm{p} / \mathrm{kWh}$ & $3535 \times 7$ year & IES \& SPVFTC & 25 & $200 \mathrm{~m}^{2}$ & 20,800 & 12,345 \\
\hline GSHPs $^{\mathrm{a}}$ & $44,000^{\mathrm{b}}$ & 102,000 & $3400 \times 17$ year & Manual Calculation & 30 & $750 \mathrm{~m}^{2}$ trench & 20,000 & $10,435^{c}$ \\
\hline Biomass boiler & 20,500 & 103,200 & $3440 \times 24$ year & TRECO & 27 & $120 \mathrm{~m}^{3}$ storage & 20,250 & 37,800 \\
\hline
\end{tabular}

a http://www.greenspec.co.uk/ground-source-heat-pumps.php.

b GSHPs cost $=$ capital cost + running cost $=£ 30,000(£ 1000 / \mathrm{kW})+£ 14,000$ (running \& maintenance 15 year $)=£ 44,000$.

c $\mathrm{CO}_{2}$ saving $=20,000(\mathrm{kWh} /$ year $) \times 0.54\left(\mathrm{kgCO}_{2} / \mathrm{kW}\right)=10,800\left(\mathrm{kgCO}_{2} /\right.$ year $), 20,000 \times 0.135=364.5,10,800-364.5=10436[$ http: $/ /$ www.kensaengineering.com/].

Table 4

Simulation results for design alternatives.

\begin{tabular}{|c|c|c|c|c|}
\hline Criteria & Alternative W & Alternative X & Alternative Y & Alternative Z \\
\hline $\mathrm{CO}_{2}$ emission & $68 \mathrm{CO}_{2} \mathrm{~kg} / \mathrm{m}^{2} /$ year & $62 \mathrm{CO}_{2} \mathrm{~kg} / \mathrm{m}^{2} /$ year & $40 \mathrm{CO}_{2} \mathrm{~kg} / \mathrm{m}^{2} /$ year & $38 \mathrm{CO}_{2} \mathrm{~kg} / \mathrm{m}^{2} /$ year \\
\hline Heat gain/loss ${ }^{a}$ & 18 & 15 & 10 & 15 \\
\hline Renewable energy supply & $10 \%$ & $10 \%$ & $10 \%$ & $10 \%$ \\
\hline Comfort - occupied & 50 & 25 & 40 & 20 \\
\hline Energy consumption & $310 \mathrm{kWh} / \mathrm{m}^{2} /$ year & $280 \mathrm{kWh} / \mathrm{m}^{2} /$ year & $190 \mathrm{kWh} / \mathrm{m}^{2} /$ year & $165 \mathrm{kWh} / \mathrm{m}^{2} /$ year \\
\hline Capital cost & $£ 3,800,000$ & $£ 3,800,000$ & $£ 3,950,000$ & $£ 4,000,000$ \\
\hline LCCA for 30 year & $£ 6,007,100$ & $£ 5,783,500$ & $£ 5,269,500$ & $£ 5,135,000$ \\
\hline Compliance result & Fail & Pass & Pass & Pass \\
\hline Potential of CSH level & Not achieved & Not achieved & Not achieved & $2(* *)$ \\
\hline
\end{tabular}

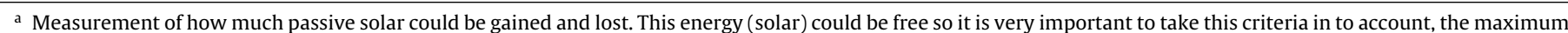
gain and minimum loss is, $15 \mathrm{~kW} / \mathrm{m}^{2} /$ year for new building design and $25 \mathrm{~kW} / \mathrm{m}^{2} /$ year for retrofit (Committee on Climate Change report, 2010).

ducted using IES. The design assessments are checked against the relevant sustainability standards and regulations, benchmarks and the client's requirements in the next stages of the framework (see stage $\mathrm{C} 1.5$ in Fig. 1) which in this case is the CSH. The potential $\mathrm{CSH}$ score for the initial building designs were very poor. Therefore the output of the energy simulations of the building designs were used to inform the development of a hybrid design (see Fig. 3 alternative $Z$ ). The hybrid design was checked against the relevant sustainability standards, regulations and benchmarks and the client's requirements (see Table 4). In this case the assessment equates to $27.2 \%$ of the potential total CSH credit points available (see Fig. 4).

The final stage of the process involves using the Sustainable Design Optimisation Tool developed within this research to support clients to select the best option from the alternative designs available. The AHP decision making method, adopted requires

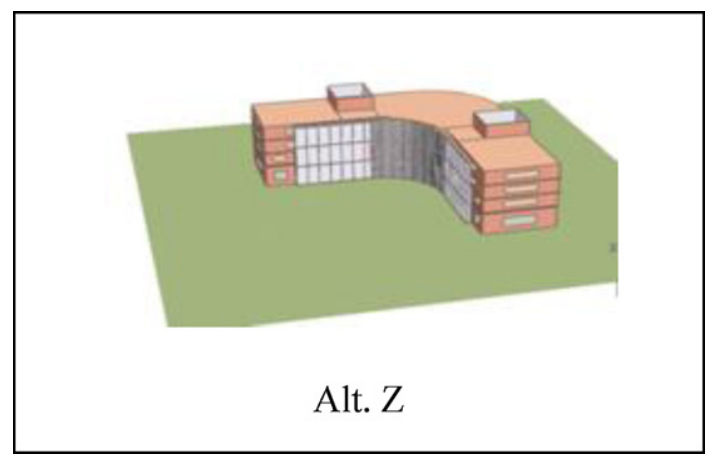

Fig. 3. Hybrid design alternative.

\begin{tabular}{|c|c|c|c|c|c|c|c|c|c|c|c|}
\hline Alternative & Assessment methods & Criteria & Input Data & Weight & Input X Weight & Standard \& Benchmark & Units & Compliance & Count & Result & CSH / BREEAM Rating \\
\hline Type of building & \multirow[t]{15}{*}{ EIA } & CO2 emission & 28 & 1 & 28 & 73 & $\mathrm{~kg} / \mathrm{m} 2 / \mathrm{yr}$ & Yes & & & \\
\hline \multirow{19}{*}{ Residential New } & & Heat gain/loss & 15 & 1 & 15 & 15 & $\mathrm{~kW} / \mathrm{m} 2 / \mathrm{vr}$ & Yes & & & \\
\hline & & Renewable energy & $10 \%$ & 1 & 0.10 & $10 \%-15 \%$ & $\%$ & Yes & & & \\
\hline & & \begin{tabular}{|l|} 
Internal light \\
\end{tabular} & $70 \%$ & 1 & 0.7 & 0.4 & $40 \%-70 \%$ low & Yes & & & \\
\hline & & \begin{tabular}{|l|} 
Comfort-occupied \\
\end{tabular} & 20 & 1 & 20 & $20 \%-5 \%$ & $\%$ & Yes & & & \\
\hline & & \begin{tabular}{|l|} 
Energy consumption \\
\end{tabular} & 165 & 1 & 165 & 291 & $\mathrm{KWh} / \mathrm{m} 2 / \mathrm{vr}$ & Yes & & & \\
\hline & & TER (BET<=TER) & 45 & & & & & & & & \\
\hline & & Material & A & & A & $A+, A, B, C, D, E$ & & Yes & & & \\
\hline & & Roof & $a+$ & & & & & & & & \\
\hline & & External walls & $a+$ & & & & & & & & \\
\hline & & Internal walls & $\mathrm{b}$ & & & & & & & & \\
\hline & & Floors & $a$ & & & & & & & & \\
\hline & & Windows & a & & & & & & & & \\
\hline & & & & & & & & & 7 & Yes & \\
\hline & & & & & & & & & & & \\
\hline & \multirow{5}{*}{ LCCA } & & & & & Stakeholder view & & & & & \\
\hline & & Capital cost & $4,000,000$ & 1 & 4000000 & 4100000 & & Yes & & & \\
\hline & & Energy cost 30yr & $1,217,700$ & 1 & 1217700 & 6000000 & & Yes & & & \\
\hline & & Biomass boilar & 20,500 & 1 & 20500 & 131000 & & Yes & & & CSH credit available \\
\hline & & Pay back 30yr & $-103,200$ & 1 & -103200 & 700 & & Yes & 4 & Yes & 27.2 \\
\hline \multirow[t]{2}{*}{ Z } & & sum & $5,135,000$ & & & & & & & & Final CSH level \\
\hline & & & & & & & & & & & $53 \%$ \\
\hline \multirow{2}{*}{$\begin{array}{|ll|}\text { Result } & \\
& \\
& \text { Pass } \\
\end{array}$} & & & & & & & & \multirow{2}{*}{\multicolumn{3}{|c|}{$\begin{array}{c}2 \\
\text { AHP renewables }\end{array}$}} & $2(* *)$ \\
\hline & & & & & & & & & & & AHP Optimisation \\
\hline
\end{tabular}

Fig. 4. Screen shot of output from the Sustainable Design Optimisation Tool (for compliance). 


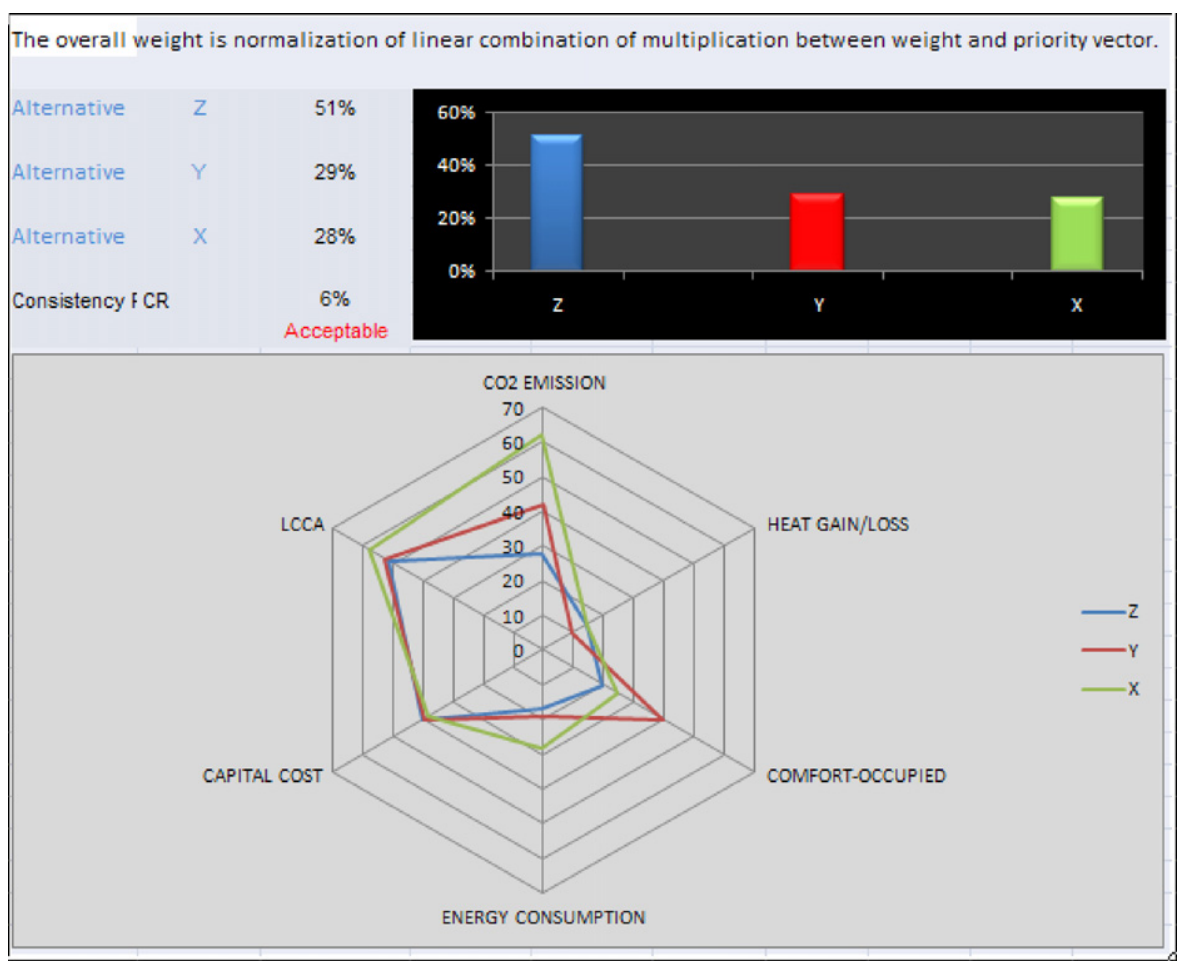

Fig. 5. Calculation and visualisation of the criteria ratings for the different design alternatives.

weightings assigned to each criterion considered in the process, each of which relates to the measured values for the different design alternatives on a performance scale of $1-9$. In the case study presented here the criteria considered are $\mathrm{CO}_{2}$ emissions, capital cost, energy consumption and heat gain/loss. In line with the hypothetical client brief, capital cost and energy consumption were given the highest priority within the AHP process utilised and the results are illustrated within Fig. 5. This figure graphically illustrates that alternative $\mathrm{Z}$ is the best option for the client.

\section{Discussion and conclusions}

The recognition of the need for carbon reduction from the built environment, along with EU directives, more stringent building regulations and general environmental concerns has lead a number of researchers to develop general lifecycle design frameworks for buildings to support energy efficient building design. However as mentioned earlier, the approaches adopted often demand that architects and building contractors completely transform current building design practice. The approach adopted in the research presented here is somewhat different. This article has argued that there is a pressing need for the integration of the methods and tools to support sustainable design with architectural practice. The research presented provides practical guidance to design professional on how and when to use building energy simulation tools and sustainable building codes to support environmentally sound design practices within current business processes. This is achieved by integrating the framework with within the Royal Institute of British Architects (RIBA) 'Plan of Work Stages' (RIBA, 2008) and identifying and filling some of the gaps in current tools.

The inclusion of a Sustainable Design Optimisation Tool developed as part of this research simplifies the process of checking multiple design options for design compliance, as interviews and literature review indicated that if this process is too onerous it will be rejected by architectural professionals due to cost and time constraints. Incorporating a trade-off or optimisation function within the Sustainable Design Optimisation Tool reduces the level of expertise necessary to interpret the results of the energy simulations thus it reduces one of the major barriers to the use of energy simulations in the design of buildings, namely the level knowledge and expertise required for interpretation (Schlueter \& Thesseling, 2008). It also means that the approach adopted is flexible enough to ensure that the clients' specific requirements can be made into a fixed priority as is often necessary for any architectural design.

The case study presented illustrates that current tools and methods can be integrated to support consideration of the energy performance of a building design when the opportunity to substantially improve the energy performance of that design is still open. However further research is required to support the use of these approaches by architectural professionals working in the construction industry. This could take the form of Knowledge Transfer Partnerships or integrated research projects which are conducted in conjunction with architectural and construction professionals. Ideally the next step in the research presented in this article is to run a live case study to see if the framework and tools are feasible within the real world.

\section{References}

Armines, P., Circe, S., Kth, G., et al. (2010). Energy saving through promotion of life cycle assessment in buildings, deliverable D2.1 state of the art report on LCA in buildings, http://ieea.erba.hu/ieea/page/Page.jsp?op= project_detail\&prid=1554\&side=downloadablefiles

Bazjanac, V. (2003). Improving building energy performance simulation with software interoperability. In Eighth international IBPSA conference Eindhoven,

Bevan, E., Cavanagh, J., \& Broks, V. (1994). An assessment of renewable energy for the UK, Great Britain. Dept of Trade \& Industry, Energy Technology Support Unit (ETSU).

BREEAM (2005). Environmental assessment method. BREEAM Offices, perassessment, http://www.breeam.org/ [02.05.10].

Building Research Establishment (2008). BREHAM BRE environmental \& sustainability standard, BREEAM, education, BES 5051 issue 1.0, 3.0, assessor manual, http://www.designlighting.co.uk/pages/technical/breeam/docs/BREEAM Education_2008 Issue 2.0.pdf [08.06.11].

CIBSE Guide A. (2006). Environmental design. London: CIBSE.

CIBSE Guide F, Energy efficiency in buildings, 2nd ed. (2004). Energy efficiency in buildings. London: CIBSE. 
Committee on Climate Change report (2010). Renewable energy review, exclusive summary, http://www.theccc.org.uk/reports/renewable-energy-review [21.06.11].

Communities and Local Government Code for Sustainable Homes (2006). A stepchange in sustainable home, building practice, http://www.planningportal. gov.uk/uploads/code_for_sust_homes.pdf [08.06.11].

Communities and Local Government (2008). A guide to energy performance certificates for the construction, sale and let of non-dwellings, 2 nd ed. July, http://www.communities.gov.uk/documents/planningandbuilding/pdf/ nondwellingsguidance.pdf [08.06.11].

Crosbie, T., Dawood, N., Dean, J., Loh, E., Madrazo, L., Vidal, J. (2008). Review of the current state of energy profiling technology, IntUBE report, work package 3 , deliverable 3.12008 .

Crosbie, T., Dawood, N., \& Dean, J. (2010). Energy profiling in the life-cycle assessment of buildings. Management of Environmental Quality, 21, 20-31.

Davis, A. J. \& Schubert, R. P. (1981). Alternative natural energy sources in building design, 2nd ed. Van Nostrand Reinhold: New York.

Department of Energy \& Climate Change 2050 Pathways analysis: The 2050 Challenge (2011). http://www.decc.gov.uk/en/content/cms/tackling/ 2050/2050.aspx [08.06.11].

Department of Trade and Industry (2007). Meeting the energy challenge a white paper on energy, http://stats.bis.gov.uk/ewp/ewp_full.pdf May [08.06.11].

Donnellan, C. (2008). Energy matters, independence issues. Education Publishers, 97, 8-25.

Energy Capital Allowance (2010). http://www.eca.gov.uk [08.06.11]

European Commission. (2008). Doing more with less: green paper on energy efficiency. Luxembourg: Office for Official Publications of the European Communities. http://ec.europa.eu/energy/efficiency/doc/2005_06_green_paper_book_en.pdf [08.06.11].

Hand, J. W., Crawley, D. B., Don, M., \& Lawrie, L. K. (2008). Improving non-geometric data available to simulation programs. Building and Environment, 43, 674-685.

Howarth, G., \& Hadfield, M. (2006). A sustainable product design model. Materials and Design, 27, 1128-1133.

Jacobs, P., \& Henderson, H. (2002). State-of-the-art review whole building, building envelope, and HVAC component and system simulation and design tools. Architectural Energy Corporation.

Karola, A., Lahtela, H., hanninen, R., Hitchcock, R., Chen, Q., Dajka, S., et al. (2002) BSPro COM-server-Interoperability between software tools using industrial foundation classes. Energy and Buildings, 34, 901-907.

Keller, R., \& Kirkwood, W. (1999). The foundings of INFORMS: A decision analysis perspective. Operations Research, 47, 16-28.

Klein, R., Versele, A., \& Breesch, H. (2008). Using building information models for passivehouses: Benefits and future developments. In 12th international conference on passive houses, exhibition centre Nuremberg, 11-12 April.

Krygiel, E., Nies, B., \& Green, B. I. M. (2008). Successful sustainable design with building information modelling. Indianapolis: Wiley Publishing.
Loh, E., Crosbie, T., Dawood, N., \& Dean, J. (2010). A framework and decision support system to increase building life cycle energy performance. Journal of Information Technology in Construction, 15, 337-353.

McElroy, L. (2009). Embedding integrated building performance assessment in design practice, a thesis submitted for the degree of doctor of philosophy, energy systems research unit, Department of mechanical engineering, University of Strathclyde, http://www.esru.strath.ac.uk/Documents/PhD/mcelroy_thesis.pdf [08.06.11].

McManus, A., Gaterell, R., \& Coates, E.(2010). The potential of the code for sustainable homes to deliver genuine 'sustainable energy' in the UK social housing sector. Energy Policy, 38, 2013-2019.

National Institute of Building Sciences (2010). Optimize energy use, whole building design guide, http://www.wbdg.org/design/minimize_consumption.php [08.06.11].

Neuberg, F., Rank, E., Ekkerlein, C., \& Faulstich, M. (2003). Integrated life cycle assessment for a sustainable resource management of buildings. In Proceedings of the eighth international IBPSA conference Eindhoven, Netherlands August 11-14,

Nielsen, T. (2002). Optimization of buildings with respect to energy and indoor environment, department of civil engineering. Danmarks Tekniske University.

Olofsson, T., Schade, J., Lulea, J., Heikkila, K., et al. (2011). The InPro lifecycle design framework for buildings public report of deliverable 17 2010. http://www.inpro-project.eu/docs/InPro_LifeCycleDesignFramework.pdf [08.06.11].

Omer, M. (2008). Ground-source heat pumps systems and applications. Renewable and Sustainable Energy Reviews, 12, 344-371.

Pollock, M., Roderick, T., McEwan, D., \& Wheatly, C. (2009). Building simulation as an assisting tool in designing an energy efficient building: a case study In the IPBSA building simulation conference of simulation experts Glasgow, UK,. July

RIBA, Outline RIBA plan of work (2008). http://www.architecture.com/Files RIBAProfessionalServices/Practice/OutlinePlanofWork(revised).pdf [08.06.11].

Saaty, T. L. (1990). Multicriteria decision making. The analytic hierarchy process, PA 1990 extended edition ed. Pittsburgh: RWS Publications.

Saaty, T. L. (1994). Fundamentals of decision making and priority theory. Pittsburgh: RWS.

Schlueter, A., \& Thesseling, F. (2008). Building information model based energy/exergy performance assessment in early design stages. Automation in Construction, 18, 153-163.

Schlueter, A., \& Thesseling, F. (2009). Building information model based energy/exergy performance assessment in early design stages. Automation in Construction, 18, 153-163.

Segen Developer (2011) http://www.segen.co.uk/

The Government's Standard Assessment Procedure for Energy Rating of Dwellings, 2005 ed., revision 3, (2005).

US Department of Energy (2011). Building energy software tools directory, http://apps1.eere.energy.gov/buildings/tools_directory/ [08.06.11]. 